dead men' (p. 73) by means of carefully placing his signature (the word of his male power) on the painting. In Le Déjeuner however, there is no such attempted resolution, the word and the body are indeed shown by Pointon to be interdependent. Articulation of the word is promised (the male hand so gestures) but is not spoken. The naked body preventing his articulation is unstable, her clothes lying nearby remind us of her de-socialized position, together with all that she hides from him. But neither male nor female (not word nor body) has the power. In refusing to identify the power-holder, Manet gives the space to self-difference. It would seem that the intersubjectivity of artist and viewers of $L e$ Déjeuner can occur only in that dimension beyond the gender system.

\section{Gillian Elinor}

\section{Vested Interests: Cross- dressing and Cultural Anxiety}

\section{Marjorie B. Garber}

Routledge: New York and London 1992, ISBN 041590072 7, £25.00 Hbk

'One thing that sticks out about the codpiece...'(p. 122) is a painful pun, but forgivable were it the exception rather than the rule. However, multiplied across the 400 pages of Vested Interests: Cross-dressing and Cultural Anxiety, it is calculated to set on edge the teeth of even the most tolerant reader, particularly given Marjorie Garber's grating literary combination of twee wordplay and ingenuous insertion of the authorial voice. Glib chapter and subheadings - 'Clothes encounters of the third kind' - are matched by a multiplicity of abstruse and unexplained introductory quotations; while paragraphs which open with, 'It is not clear to me who reads these novels

\section{Notes}

1 The case cited by Pointon is a review by Anita Brookner in The Observer 15 May 1988.

2 Here Pointon cites C. Duncan's article as 1982, in its reprint form and date; it was first published in Artforum in 1973 , and at that time represented one of the earliest, and extremely helpful, feminist art historical analyses.

3 See especially chapter, 'Notes on some schizoid mechanisms' (1940)

\section{References}

CORNELL, D. and THURSCHWELL, A. (1987) 'Feminism, negativity, intersubjectivity' in S. Benhalib and D. Cornell, editors, Feminism as Critique: Essays on the Politics of Gender in Late Capitalist Societies Cambridge: Polity Press.

IRIGARAY, Luce (1985) This Sex Which is Not One, trans. C. Porter and C. Burke, Ithaca: Cornell University Press.

KRISTEVA, Julia (1982) Powers of Horror: An Essay in Abjection New York: Columbia University Press.

MITCHELL, Juliet (1986) editor, The Selected Melanie Klein Harmondsworth: Penguin.

PoINTON, Marcia (1989) 'Wimagery' Art History March. and magazines, but some statistics suggest that male transvestites are largely middle-class, heterosexual and married', (p.96) only serve to further undermine the author's authority.

This immature prose style is coupled with a tendency not to define her terms, and to casually toss in complex and undersubstantiated conclusions while spending pages chattily discussing irrelevant material. For example, Garber uses the historically and culturally specific 'gender bending' (p. 62) in relation to Harvard's 'Hasty pudding theatricals' of the mid-nineteenth century. Although she is Professor of English at Harvard University, Garber also apparently finds the concept of 'great theater' unproblematic, given her statement that: "The notion that there has to be a naturalness to the sign is exactly what great theater puts in question.'

Similar linguistic imprecision is 
demonstrated by Garber's willingness to ask the reader to: 'Consider such cannonical moments of greatness in the history of drama as the ancient Greek theater; the public theater of the English Renaissance; Kabuki and Noh theaters in Japan; the Chinese opera. This is a short list which could easily be made longer. But it is enough to give the sense that transvestism and theater are interrelated, not merely "historically" or "culturally", but psychoanalytically, through the unconscious and through language' (p. 39-40). Garber is, however, less willing either to support this sweeping statement, or even to explain the role of transvestism in the cited dramatic traditions. She is also guilty of neither numbering her illustrations nor referring to them within the text, a fundamental omission which suggests that Vested Interests may have been written and/or published in haste.

Garber's ability to undersubstantiate her conclusions is especially frustrating given her continual insertion of irrelevant information, anecdotes and asides. For example, Information for the Female-to-Male Crossdresser and Transsexual is patronizingly introduced as, 'this invaluable and immensely readable little book' (p. 44). Garber then quotes its advice on breast binding and crotch padding using two men's "'dress socks" - at length, before informing the reader that: 'as it happens, in men's clothing parlance this bulge in the trousers is technically described as "dressing", and is taken into account by custom tailors, who will ask a man whether he "dresses right" or "dresses left" (p. 46). This discussion extends across several pages with no greater justification than to support Garber's uncontroversial assertion that, in the lives of the transvestites or transsexuals who find this pamphlet helpful, the "construction" [of gender] itself becomes literalized and essentialized' (p. 47).

Vested Interests is divided into two sections, 'Transvestite logics', which 'explores the way that transvestism creates culture' and 'Transvestite effects', which addresses 'the way that culture creates transvestites' (p. 16). The book is structured around Garber's theoretical premise that the transvestite acts as an indication of "category crisis," disrupting and calling attention to cultural, social, or aesthetic dissonances' (p. 16). Ultimately, she asserts, 'transvestism is a space of possibility structuring and confounding culture: the disruptive element that intervenes, not just a category crisis of male and female, but the crisis of category itself' [Garber's italics] (p. 17). Given the book's theoretical motivation, Garber reasonably disavows any attempt 'to produce a seamless historical narrative of the "development" of the transvestite figure' (p. 16). Rather, Vested Interests utilizes an undeniably fascinating miscellany of sources - the plays of Shakespeare, Madonna's pop videos, the film Tootsie, or transvestite/transsexual self-help manuals with Garber ranging from one to another in support of her argument.

Much of this argument rests upon the theories of Freud and Lacan, and large areas of Garber's analysis can be frustratingly difficult to follow for the reader who is unfamiliar with their work. More so, since her convoluted prose style mystifies rather than clarifies, while the book's linguistic and theoretical imprecisions prejudice one against painstakingly pursuing Garber's more complex psychoanalytic discussions. For example, in the context of her argument 'that fetishism is a kind of theater of display - and, indeed, that theater represents an enactment of the fetishistic scenario' (p. 120), Garber writes: 'That the fetishistic patient is sometimes in fact a transvestite renders more complex but also more plausible the argument that the transvestite on stage or in culture is himself/herself a festishization. The fetish is a 
metonymic structure, but it is also a metaphor, a figure for the undecidability of castration, which is to say, a figure of nostalgia for originary "wholeness" - in the mother, in the child. Thus the fetish, like the transvestite - or the transvestite, like the fetish - is a sign at once of lack and its covering over, as in the case of Freud's patient's athletic supportbelt - a garment very similar to devices worn, as it happens, by some present-day female-to-male transvestites' [Garber's italics] (p. 121).

To utilize a wide variety of texts, while also respecting their inherent differences, and simultaneously to sustain an argument throughout a book of this length is a difficult undertaking, and one to which
Garber appears unequal. Garber has amassed a fascinating and extensive collection of historical material, together with some potentially illuminating theoretical concepts. However, in order to qualify as a useful academic text Vested Interests needs to be ruthlessly edited and rewritten. As it stands, the book resembles the 'Fool' and his outsize "bauble", an allusion to the common wisdom that fools had extra large genital equipment to compensate ... for their lack of brain-power' (p. 124). Vested Interests boasts an over-inflated body of material, but one which ultimately fails to satisfy its reader.

\section{Katrina Rolley}

\section{The Colour of Love: Mixed Race Relationships}

Yasmin Alibhai-Brown and Anne Montague

Virago: London, 1992

ISBN 1853812218 , £6.99 Pbk

\section{Understanding Everyday Racism: An Interdisciplinary Theory}

Philomena Essed

Sage: London 1991

ISBN $0803942567, £ 16.95 \mathrm{Pbk}$

ISBN 0803942559 , £34 Hbk

\section{'Race', Culture and Difference}

Edited by James Donald and Ali Rattansi

Open University, Sage: London 1992 ISBN $0803985800, £ 10.95 \mathrm{Pbk}$ ISBN $0803985797, £ 35 \mathrm{Hbk}$

As Europe threshes around in the throes of confusion over the character and form that its Fortress should be given, the challenges facing activists against racism, and those working in the area of cultural studies seem at times to overwhelm all but the most astute thinkers. Yet the need for intellectuals to address the issues with courage and clarity has never been greater.

Contemporary European states have reacted to the presence of several million immigrants of nonEuropean origins with a mixture of containment and control, with many countries still talking about integration, decades after the first racial attacks made it obvious that no matter what black people did, or whether or not they 'adjusted', white racism was intent on obstructing it. Nowadays we are witnessing new waves of racial violence, not to mention new techniques of regulation and administrative coercion developed by the European states to deal with the situation. The feature which bureaucratic and mob racism share is that both are about the assertion of the New European identity as an Aryan one, and there is nothing new about the xenophobic rejection of nonwhite people. With the stopping of black immigration ('New Commonwealth immigration' in the official jargon) black Europeans have become internees in the Fortress, placed under increasingly heavy surveillance in a world ever more sharply divided between the affluent élites of the West and that of 